\title{
The promise of a potential theoretical framework in international entrepreneurship: An entrepreneurial orientation-performance relation in internationalized context
}

\author{
Hamid Etemad ${ }^{1}$
}

Published online: 7 June 2015

(C) Springer Science+Business Media New York 2015

This brief editorial note further builds and elaborates on the previous one appearing in the first issue of the 13th volume of the journal ( $J$ of Int Entrep, V13-No.1, Winter 2015). While the entrepreneurial characteristics and processes have distinguished the field of international entrepreneurship (IE) from other allied fields with emphasis on the institutional aspects, there exists a concern in the IE scholarly community that the developmental path of the field has gravitated more towards internationalization processes and institutional aspects with less emphasis on the entrepreneurial aspects of the field. At the same time, entrepreneurial studies, and entrepreneurship as a field of scholarly inquiry, have flourished. This concern motivated the previous editorial note, which highlighted aspects of the relationship between entrepreneurial orientation (EO) and performance $(\mathrm{P})$ in international context. We are, therefore, returning to the underlying theme to highlight the four articles included in this issue, each in its own specific international context. This editorial begins with a very brief revisiting of the previous editorial before examining the four articles of this issue from the perspective of EO-P relationship.

A Brief Revisiting of EO-P Framework in International Context. Scholars of entrepreneurship, going as back as Hayek (1945) and Kirzner (1973), have maintained consistently that there would be no entrepreneurship without the knowledge that would lead to opportunity recognition and its subsequent exploitation by acting on it (Hills et al. 1997). In IE, knowledge and opportunity are likely to be conceived in one and exploited in another environment. The process is, therefore, embedded in international, if not global, context(s). In the previous editorial note, we suggested that the evolving construct of entrepreneurial orientation, with its many modifications over time, was an effective vehicle for introducing the basics of entrepreneurship concepts in IE and

Hamid Etemad

hamid.etemad@mcgill.ca

$1 \quad$ McGill University, Montreal, Canada 
operationalizing it through specific components, each representing a dominant attribute of entrepreneurship. For example, Miller (1983) proposed three basic attributes (i.e., Innovativeness, Pro-activeness, and Risk-taking) and Lumpkin and Dess (1996) added two more (i.e., Competitive Aggressiveness and Autonomy). The maintenance of these basic attributes by a firm could characterize, and possibly preserve, the spirit of entrepreneurship and entrepreneurial orientation even when the institution of the firm grew stronger over time. Collectively, they could also project a specific entrepreneurial profile as the basis of a strategic posture in an entrepreneurially oriented firm. Although the evidence points to a general support for EO-P relations in the firm's relatively safer and familiar home market, the diverse characteristics of international market environments may require further developments to account for that contextual diversity.

Internationalization exposes the firm to different markets, requiring sensitivity to different country-market behaviors, if not some knowledge of the environments, for their potential impact of the environment on opportunity and its realization. Similarly, entry decision into a new market requires some prior information followed by a need to learn about market characteristics so that the firm can adjust its entrepreneurial orientation and strategic posture to market requirements for gainful performance, independently or collaboratively by partnership with other agents and firms (Nooteboom 2004), when and if necessary. The efficacy of these processes and the extent of their impact on performance will not only depend on the firm's initial EO (including innovativeness or innovative orientation (IO)) but also on its marketing orientation (MO), learning orientation (LO), and collaborative orientation (CO) in order to properly adjust strategy for success in a given market and also for capitalizing on potential differences among markets.

MO refers to a firm's understanding of its competitive market environment and on its focus on meeting its customers' needs. Market-oriented firms are likely to be more successful in diverse markets than others. Operationally, the emerging concept of customer-centric strategy is parallel to, if not a part of, the firm's MO, which requires a relatively high sensitivity to differences in customers' need and market behaviors. LO refers to a firm's commitment, or disposition, to learning from every situation to which it is exposed (Crosson and Berdow 2003, Crossan et al. 1999). Naturally, a firm can also learn from market behaviors and others in the market, especially those of competitors. Such learning will initially occur at the individual level (e.g., by the entrepreneur) and is tacit before it becomes explicit through organizational learning (Crossan et al. 1999). Logically, a higher LO enables the firm to learn faster and more effectively by itself, as well as with and from other's experience, to attain higher and better performance outcomes than those with lower LO. Such learning can also enhance the firm's response to market expectations and trend for higher customer satisfaction, especially when there is a paucity of pertinent information or the environmental and institutional distances are longer, making learning relatively difficult. Furthermore, the state of the firm's resources, capabilities, and risk-taking may favor a form of collaborative approach, as opposed to independent operations, in a foreign market or international markets as a whole. Collaboration will involve some form of partnership and needs to be assessed in light of the firm's openness, or its functional ability, to collaborate with others and counterbalance against what it might impose, before committing to do so. The logical interactions among the entrepreneurial, market, learning, and collaborative orientations introduce some complexity as such interrelation and interactions impact the 
entrepreneur's overall entrepreneurial profile and firm's strategic posture. ${ }^{1}$ Stated briefly, but differently, the internationalized EO-P relation can serve as a theoretical framework to enrich our analysis and allow for preserving the entrepreneurial character of IE without hindering other aspects.

\section{Papers contained in this issue}

The first paper in this issue, co-authored by Ivan De Noni and Roberta Apa, is entitled as "The moderating effect of exploitative and exploratory learning on internationalization-performance relationship in SMEs". Although this paper's focus is on the interaction between leaning and performance, it explores the intersection between the components of EO and internationalization processes as well as their respective impacts on future performance. It raises four logical and related research questions: i) Are exporting small- and medium-sized enterprises (SMEs) more learningoriented than their domestic counterparts, ii) Does learning affect internationalizationperformance relations, iii) How do exploitative and exploratory learning moderate the exporting effects in SMEs' performance, and iv) Does internationalization affect SMEs' performance?

Theoretically, the marketing orientation of a firm - the firm's desire and capability to serve the market well and create the highest possible customer value-requires information and knowledge; some of which are tacit and need to be learned experientially (Johanson and Valhne 1977, 2003; Erikson et al. 1997, 2000), directly, or acquired through collaboration with agents possessing them. Both cases enable the firm to add to the stock of its knowledge resulting in better informed decisions. Organizational learning (Crosson and Berdow 2003; Crossan et al. 1999, 2011) activities result in further building on a firm's existing knowledge and developing new knowledge, to which March (1991) referred as learning by exploitation or learning by exploration, respectively. Learning about potential export markets informs the firm about their requirements in light of its capabilities and enables it to determine if it can rely on exploitative learning alone or needs to launch exploratory learning as well. Logically, they enable the firm to improve upon its capabilities and the consequent performance.

The empirical findings of the paper confirm theoretical expectations and indicate that pro-active exploratory learning is critical to successful exporting as it enhances the firm's export MO and its overall performance. Furthermore, learning and internationalization have positive effects on the firm's performance outcomes. Stated differently, this paper's finding points to the illuminating power of EO-P relations as a framework for assessing the influence of various orientations, if not practices, on decisions and their respective impacts on outcomes, although the primary aim of the paper was not exploring the validity or the nature of such relations or respective decisions.

The second paper in this issue, co-authored by Thomas W. Thurner, Mikhail Gershman, and Vitaly Roud, is entitled as "Partnership as internationalization strategy: Russian entrepreneurs between local restrictions and global opportunities". The paper

\footnotetext{
${ }^{1}$ Given the complexity of interdependencies and interactions, Lumpkin and Dess (1996) suggested that the initial five components (specified above) could adopt different values, each with varying effects on performance across time and space.
} 
reviews the internationalization difficulties faced by small Russian-based firms in particular and those based in emerging countries in general. It discusses typical problems experienced by these firms, including the shortage of "risk capital", cuts in private and public funds for supporting $R \& D$ expenditures resulting in firms falling behind firms based in the advanced countries, and restrictive policies and practice regarding international investment and trade activities, among others, hindering these firms' successful internationalization. Against that background, and in spite of largescale cooperation between some large Russian and Western companies joint efforts, mainly in natural resources, the authors suggest that cooperative (or collaborative) strategies between the Russian SMEs and their Western counterparts have not received much attention, thus an opportunity to address the gap. Although the contribution of inter-firm collaboration and network partnership to the internationalization of smaller and younger SMEs, especially born globals, has been well-documented (Sharma, Blomstermo 2003), little is known about such collaborations between firms based in the advanced and emerging economies. The authors suggest that networks have played critical roles in creating and exploiting opportunities prior to, during, and after internationalization, even before the firm's establishment in some cases. Accordingly, this paper examines cooperation between the Russian firms and others based in advanced economies for developing and commercializing technology, mainly by born globals or firms that aspire to become born globals soon. The authors suggest that technology-led born globals do not gradually accumulate resources and capabilities as competitive market pressures compel them to explore international market opportunities relatively quickly and from the beginning. When the know-how (or knowledge) is geographically dispersed and held by a few individuals, networks are not only necessary for, if not critical in, developing opportunities and possibly common assets in a timely fashion but they can also enhance efficiency and global competitiveness (Birley 1985, Elango and Pattnaik 2007). At times, international collaboration among future team members (and networks) points to potential opportunities predating a firm's establishment and appears necessary to successful operations and sustainability of technology-led born globals. Such needs for collaboration point to the necessity of developing strategic international (cross-border) collaborative partnerships for timely and successful internationalization of firms in environments such as Russia's.

The mixed methodology of this paper identifies a few important findings, including the following: i) Russian firms find collaborations with cross-border firms as resource intensive, but rewarding, ii) national support institutions, such as the Foundation for Assistance to Small Innovative Enterprises (FAISE), which is the oldest and largest institution of its kind, are supportive of such collaborations, iii) a larger number of international collaborations are in R\&D and science and technology than those involving other value chain activities, iv) international collaboration is the preferred strategic choice for internationalization of the Russian technology-led born globals, v) crossborder collaborations help partner firms to broaden their international horizon, and vi) it assists and hastens the developmental pace of Russian born globals, among other benefits.

In summary, this paper points to the positive interaction among few components of entrepreneurial orientation-e.g., innovativeness, risk-taking, market, and collaborative orientations. The combination of these orientations, and their respective and collective interactions, in spite of their costs and environmental rigidities, is found to influence 
consequent operations and reported to be conducive to internationalization, especially in technology-led born globals.

The third paper of this issue, co-authored by Valerio Veglio and Antonella Zucchella, is entitled as "Entrepreneurial firms in traditional industries. Does innovation matter for international growth?" This paper is complementary to the previous two and shares some aspects with them, including the impact of innovation and possible collaboration for internationalization.

The authors observe that the firm's innovativeness, supported by its own R\&D, can serve as a unique source of competiveness and foster internationalization. However, traditional industries (e.g., apparels, furniture, leather, textiles, and the likes) are dominated by relatively smaller firms, where the entrepreneur and top management team coincide and where they suffer from the liabilities of smallness. Furthermore, the traditional nature of such industries has not relied on massive product-innovations to either preserve current competitive positions or to create incremental competitiveness. The extant literature regarding the above characteristics suggests that firms in such industries are less likely to be successful in international markets. This paper, however, reports on internationally successful cases. Although efficiency-seeking process-innovations, mainly at the industry level, have been ongoing, their consequent improvements do not generally attract market attention unless the higher customer value (through lower costs, improved quality, or a combination of both) is brought to market attention. Their international competitiveness is in their ability to follow or anticipate market trends (i.e., based on their market orientation) and responding with new appealing designs, based on their special entrepreneurial capabilities, or entrepreneurial orientation, complemented by their reliance on complementary intangible assets, such as "made in" and "brand equity", among others. Although the strategic value of such intangibles is well-recognized in marketing, investment in intangibles (e.g., brands) to attain incremental international competitiveness has not been broadly utilized by smaller firms. The paper reports that the increased competitiveness of the focal firms is based on combining certain tangible and intangible attributes, especially when they are mutually complementary, to generate unique attractive appeals that would be readily valued by customers - new designs and made-ins (made in Italy in this case) well qualify as they mutually and synergistically complement very well.

This paper multi-method analysis reports that more than one-third of the firms in the Italian traditional industries attain export intensities (ratio of exports to turnover) in the range of 5 to $25 \%$. Furthermore, SMEs with high export intensities (reported as $31 \%$ ) invest more in new designs than SMEs with low export intensities (reported as $14 \%$ ), which is mainly in the form of continuous improvements in new product designs (e.g., esthetic aspects). Although these SMEs are pressured by low cost producers from the emerging economies on one hand and luxury brands on the other, the creative power of their employees and the high entrepreneurial orientation of their entrepreneurs, or top management team, enable them to sustain international competitiveness, thus pointing not only to the power of entrepreneurial value adding activities but also to an alternative model to the traditional model of innovativeness based on high internal R\&D investments as the source of global competitiveness.

The fourth and final paper in this issue, authored by Sarka Zapletalova, is entitled as the "Models of Czech Companies' internationalization". Although the main emphasis of this paper is on internationalization as stated in its research questions - what are the 
internationalization processes of entrepreneurial activities of Czech companies and if they follow a specific model of internationalization?-its review of the literature and findings point to the entrepreneurial activities of the Czech firms under strong competitive pressure from national and international firms in the small Czech market. Based on a sample of some 297 firms responding to a questionnaire (for $74 \%$ response rate), the paper reports that most internationally active companies (i.e., $82 \%$ ) were SMEs in manufacturing (i.e., $54 \%$ ), with their first entry into international markets occurring within three years from their founding (i.e., $56 \%$ ). Their average export intensity approached $21 \%$ with low market and cultural diversification-i.e., they mainly entered in markets neighboring the Czech Republic (e.g., Slovakia, Poland, and Germany) and mostly in the cultural cluster of Eastern European and German cultures.

In addition to the average profile of Czech internationalized and internationalizing companies, the paper reports that the pattern of their internationalization falls into five separate cluster models. These clusters are characterized by two distinguishing dominant factors - scope of internationalization (number of international markets entered) and timing of entry into international markets (number of years from founding). As mentioned above, the largest clusters are characterized by firms with low export intensities and relatively recent entries in the past 10 to 15 years.

From an entrepreneurial orientation perspective, the five company clusters point to an interesting pattern of internationalization consistent with both the slow process model of internationalization and the earlier discussions of entrepreneurial orientation as a framework for better understanding of entrepreneurial internationalization decisions and practices. Given the Czech economy's recent transition to an open and free enterprise system, Czech firms' average knowledge of international markets beyond Eastern European country-markets appears to be relatively low as compared to their counterparts in the European Union. Czech firms' low-risk entry methods into markets with relatively low institutional (or psychic) distance (e.g., the Eastern European or neighboring markets) and possibly in partnership with more knowledgeable and experienced firms are consistent with risk-mitigating and collaborative orientations. These orientations are what practically all clusters exhibited. Similarly, Czech firms collaborated with non-Czech partners when they opted for relatively more distant economies of the Western European markets.

In closing, one conclusion stands out: the relatively large number of internationalizing, or internationalized, entrepreneurial firms have embarked on practices that are consistent with and supportive of the entrepreneurial orientationperformance relationship in international context. Stated differently, this framework is well-capable of introducing the entrepreneur and incorporating associated entrepreneurial practices into the evolving theories of IE as well as shedding lights on internationalization practices from an entrepreneurial perspective.

Ironically, Etemad (2004) placed the internationally oriented entrepreneur at the center of an interactive and adaptive theory of internationalization comprising three active and influential players - i.e., the entrepreneur (or the top management team as the firms would grow larger) and the two institutions of the firm and the market. Based on the fragmented evidence at the time, he suggested that such a dynamically adaptive and interactive system (or theoretical framework) could provide for a much clearer, deeper, and richer understating of entrepreneurial internationalization than the prevailing theories then that did not consider the moderating influence and interactive roles of 
all the three players at the same time. Although an internationalized entrepreneurial orientation-performance (IEO-P) framework offers basic insight that are missing elsewhere, as discussed in this and previous editorial notes, it seems that theoretical developments are converging on the three-part interactive framework that Etemad (2004) suggested a decade ago.

\section{References}

Birley S (1985) The role of networks in the entrepreneurial process. J Bus Ventur 1(1):107-117

Crossan MM, Berdrow I (2003) Organizational learning and strategic renewal. Strateg Manag J 24:10871105. doi:10.1002/smj.342

Crossan MM, Lane HW, White RE (1999) An organizational learning framework: from intuition to institution. Acad Manag Rev 24:522-537. doi:10.5465/AMR.1999.2202135

Crossan MM, Maurer CC, White RE (2011) Reflections on the 2009 AMR Decade Award: do we have a theory of organizational learning? Acad Manag Rev 36:446-460

Elango B, Pattnaik C (2007) Building capabilities for international operations through networks: a study of Indian firms. J Int Bus Stud 38(4):541-555

Eriksson K, Johanson J, Majkgård A, Sharma DD (1997) Experiential knowledge and cost in the internationalization process. J Int Bus Stud 28(2):337-360

Eriksson K, Johanson J, Majkgård A, Sharma DD (2000) Effect of variation on knowledge accumulation in the internationalization process. Int Stud Manag Organ 30(1):26-44

Etemad H (2004) International entrepreneurship as a dynamic adaptive system: towards a grounded theory. J of Int Entrep, Spring 2(1 \& 2):5-59

Hayek FA (1945) The use of knowledge in society. Am Econ Rev 35:519-530

Hills GE, Lumpkin GT, Singh RP (1997) Opportunity recognition: perceptions and behaviors of entrepreneurs. In: Reynolds PD, Carter PWD, Davidsson P, Gartner WB, McDougall P (eds) Frontiers in entrepreneurship research. Babson College, Wellesley, Massachusetts, pp 330-344

Johanson J, Vahlne JE (1977) The internationalization process of the firm: a model of knowledge development and increasing foreign market commitments. J Int Bus Stud 8(2):23-32

Johanson J, Vahlne JE (2003) Business relationship learning and commitment in the internationalization process. J Int Entrep 1:83-101

Kirzner IM (1973) Competition and Entrepreneurship. The University of Chicago Press, Chicago

Lumpkin G, Dess G (1996) Clarifying the entrepreneurial orientation construct and linking it to performance. Acad Manag Rev 21(1):135-172

March JG (1991) Exploration and exploitation in organizational learning. Organ Sci 10(1):299-316

Miller D (1983) The correlates of entrepreneurship in three types of firms. Manag Sci 29(7):770-791

Nooteboom B (2004) Inter-firm collaboration, learning and networks: an integrated approach. Routledge, London and New York. doi:10.5465/AMR.2011.61031806

Sharma DD, Blomstermo A (2003) The internationalization process of born globals: a network view. Int Bus Rev 12:739-753. doi:10.1016/j.ibusrev.2003.05.002 